\title{
The Polemic of Worship Houses Construction in Indonesia: An Islamic and Positive Law Perspective
}

\author{
$1^{\text {st }}$ M. Akhfas Syifa Afandi ${ }^{1}, 2^{\text {nd }}$ Zulkifli $^{2}, 3^{\text {rd }}$ A'ang Subiyakto $^{3}$ \\ \{mas.achfas@gmail.com ${ }^{1}$, zulkifli@uinjkt.ac.id ${ }^{2}$, aang_subiyakto@uinjkt.ac.id ${ }^{3}$ \}
}

UIN Syarif Hidayatullah Jakarta ${ }^{1,2,3}$

\begin{abstract}
The purpose of this study is to ascertain how Islamic and Positive Law respond to the dynamics of the house of worship construction in Indonesia, which are frequently fraught with conflicting rights of worship for the majority and minority groups. Government regulations promulgated in 2006 by a joint decree (SKB) between the Ministries of Religion and Home Affairs do not fully protect minorities' rights to establish houses of worship. The research methodology used is qualitative-descriptive, with the primary data source being a literature review. The findings of this study indicate the following: 1). In 2006, the Joint Regulation Agreement (SKB) between the Ministries of Religion and Home Affairs identified decisions that continue to discriminate against minorities. 2) Islamic law scholars (fuqaha) believe that building houses of worship is permissible as long as it is justified by need (hajjah) and adheres to government regulations and decisions.
\end{abstract}

Keywords: Houses of Worship, Islamic Law, and Positive Law.

\section{Introduction}

In the last decade, a series of refusals to establish a house of worship (or to pray) have occurred repeatedly. The same cases recur, such as the Yogyakarta church construction ban, the Bekasi temple ban, and the Yasmin Indonesian Christian Church (GKI) in Bogor.[1] In addition, there was also the destruction of the Al-Hidayah mosque in North Minahasa on Wednesday, January 29, 2020.[2] The same incident occurred almost simultaneously in Tanjung Balai Karimun, Riau Islands. It occurred at the Parish Church of Saint Joseph, where people objected to its renovation process.[3]

Even though the last two events ended peacefully, they have provided lessons in ensuring religiosity in Indonesia. Even those who are victims of threats and violence in carrying out their worship are accepted by minority groups and the majority group in the country. Houses of worship are included in the constitution's section on freedom of expression and assembly, guaranteed by the 1945 Constitution of the Republic of Indonesia and international conventions. The repeated series of events, according to many experts, occurred partly because of the mutual agreement between the Minister of Religion and the Minister of Home Affairs No. 09/2006 and No. 08/2006 (from now on it was abbreviated PMB No. 09/2006 and No. 08/2008). It regulates the establishment of houses of worship, but in its realization, conflicts around places of worship continue to occur and increase from year to year.

For example, these facts include data published by several institutions such as the Center for Religious and Cross-Culture Studies at Gajah Mada University (CRCS-UGM), that in 2008 there were at least 12 cases of conflict involving houses of worship. The number 
continues to increase; there were 18 conflicts in 2009 and 39 conflicts in 2010.[4] Meanwhile, in 2014-2016, some publications from the SETARA Institute also showed the same thing. Such as the Tolerant City Index (2015), the Human Rights Performance Index (2015), and the Student Tolerance Survey (2016). In its report, SETARA Institut intends to educate the public about the condition of freedom of religion/belief in Indonesia. [5]

This chain of events was precipitated by a dispute over building permits for houses of worship. In some areas, cases are almost certainly the result of the community's rejection of certain religious groups.[4] Additionally, conflicts over the construction of houses of worship may arise due to a disagreement over whether the renovation or development plan is appropriate or violates the spatial planning concept. Islam, in and of itself, guarantees justice and tolerance for all. Stabilizing the values of justice and equality is a central tenet of religion, one of which protects the construction of houses of worship.[6] Certain Muslim scholars insist on preserving religious freedom; Islam, as a religion of grace, never once imposes the will of all human beings to share a single religion.

This paper attempts to explain how the issue of regulation of the establishment of houses of worship in the perspective of positive law and sharia (Islamic law). Can the regulations, technical and practical aspects protect all citizens' rights? Or there is comparison and discrimination of certain religious groups. And how does Islam respond to this problem? Provide a solution or even strengthen the barrier of intolerance.

\section{Methodology}

The research methodology is qualitative-descriptive, with a primary source being a literature review.[7][8] This approach examines how the dynamics of the house of worship establishment are studied through the lens of Islamic and positive law. This research drew its data from events, documents, and pertinent literature. The data were then analyzed using empirical induction based on human experience (based on analysis). This qualitative data enables a level of comprehension that transcends numerical and statistical inference.

\section{Result and Discussions}

\subsection{Regulations and Rules for the Establishment of Houses of Worship}

Regulations and policies ensuring religious harmony in Indonesia aim to create a sense of security in religion. This case is related to the regulation between the Minister of Religion and the Minister of Home Affairs No. 09 and 08 of 2006, abbreviated PMB. After a long debate, this regulation was enacted from October 28, 2005, until mutually agreed on March 21, 2006. Although it has received a lot of criticism for not being able to accommodate the rights of minorities, these articles still apply to this day. Article 14 states that the procedures and rules for the construction of houses of worship are as follows:

1. The establishment of a house of worship must meet the administrative requirements and technical requirements of the building.

2. In addition to meeting the requirements as referred to in paragraph 1, the establishment of a house of worship must meet several special needs, including: 
a. List of names and resident ID cards of users of the house worship at least 90 (ninety) people authorized by local officials following the level of territorial boundaries as referred to in article 13 paragraph 3 ;

b. Support from the local community of at least 60 (sixty) people who the head man legalizes;

c. Recommendations from the head of the district/city religious department office and;

d. Recommendations from religious community communication forums at the district/city level.

3. If paragraph (2) letter (a) is met, but a letter (b) is not, the local government is required to facilitate the availability of land for the construction of houses of worship.[9]

The two ministers' 2006 Decree (SKB 2006) was initially intended to maintain order in constructing houses of worship. Nonetheless, its implementation frequently results in discrimination against certain religious groups, particularly minorities, and conflicts between religious communities due to a lack of tolerance.[10]

\subsection{The Articles of Discrimination in the construction of houses of worship: Between Fake Tolerance and Pseudo-Freedom of Religion}

The government has regulated regulations for establishing houses of worship (SKB numbers 9/2006 and 8/2006) regarding guidelines for carrying out the duties of regional heads/deputy regional heads in religious harmony and empowering religious harmony forums. Additionally, the construction of houses of worship. According to numerous experts, this government regulation results in significant discrimination against minorities.[10]

First, there is the issue of the local government becoming politicized in the process of issuing the IMB. This is demonstrated by the incident involving a candidate for Bogor's regional head who promised not to give an IMB to a particular religion. Another instance of politicization occurs when regional executives hail from Islamist parties and are tasked with implementing an Islamist agenda in their regions. Among them is the prohibition of minorities from constructing houses of worship. The authority to recommend without legislative or civil society oversight can result in discriminatory policies.[11]

Second, The membership of FKUB (forum for religious harmony) is proportional to the number of religious adherents. The more adherents of a particular religion, the larger the membership of FKUB. Even though FKUB decisions are based on mutual agreement in PBM No. 9/2006 and No. 8/2006, in practice, FKUB decisions are frequently reached through voting. The dynamics work against minority religious adherents, who can only elect a few representatives to the FKUB. Representation also creates complications for religions with multiple denominations.

Third, the requirement for community support in the form of 60 identification cards has the potential to result in discrimination. This requirement is unquestionably not a problem in an area where the community is tolerant. Nonetheless, it will undoubtedly impede the establishment of houses of worship in an area with a low tolerance attitude. Additionally, the requirements for community support are susceptible to being commercialized.[12]

In some instances, the requirement for community support serves as a justification for certain groups to receive funding. The group promised community support in exchange for a certain amount of money being paid by the committee for the construction of a house of worship. If development requirements are not met, the development process will be harmed, and the collected support will be questioned. This situation poses no difficulty for the committee charged with the responsibility of constructing houses of worship with sufficient 
funds. However, for those lacking financial means, the requirement for community support is frequently a barrier.

\subsection{State Neutrality and Religious Rights in Indonesia}

Regulations governing the establishment of places of worship must be strengthened appropriately to ensure that another state upholds the rule of law (law enforcement). Because regardless of how well-written the material or formulation of regulations governing the establishment of places of worship is, if they are not accompanied by enforcement, their presence will be in vain. What appears to be dominant in this republic is the lax enforcement of the rule of law. The perpetrators who forced the 'house of God's closure and vandalized it were acquitted. The state apparatus does not spare the perpetrators even a shred of protection. This omission implies that the state has justified the perpetrators' actions. As a result, the government's enforcement of the rule of law must be a top priority.

When confronted with conflict, the state must always be firm, non-discriminatory, and objective (neutral). When a dispute arises over the construction of houses of worship, the condition must be equitable. The state should always rely on the constitution and the law in this context, not on particular religious doctrines (groups). The state cannot afford to lose its composure and be afraid of groups that seek to undermine religious people's rights to construct houses of worship. The state should not tolerate any party closing houses of worship forcibly and illegally. Closing places of worship for minority religious groups will only result in injustice and, if left unchecked, horizontal conflicts.

In terms of religious rights in Indonesia, they should be guaranteed by each individual's teachings and beliefs. Recognize and respect religious rights to ensure equal rights for minority groups. The minority is calculated numerically and takes the area's map and distribution into account. While Muslims are the majority in Java, they are not in Bali, NTT, or Papua. Muslims in Indonesia, on the other hand, do not face the psychological burden that other minorities do.

The issue is how to reconcile the majority's interests with the protection of minorities rights. How, in the words of Jon Elster, to strike a balance between majority rule and individual rights. It is not simple to respond. The issue of majority and minority does not pertain exclusively to one of the two. It entails two critical elements: the majority culture's readiness to serve as the primary subject and the state constitution. Indonesia's constitution contains ambiguity regarding the protection and fulfillment of religious and philosophical freedoms. To begin, several regulations emphasize the nondiscriminatory nature of the right to religious freedom and the state's responsibility for its fulfillment and protection. Second, several regulations restrict and revoke religious and philosophical freedoms.[13]

Meanwhile, the relation to human rights regulations is not clear between universal or particular, which substantially has guaranteed the rights to freedom of religion and belief.

First, universal and non-discriminatory rules were found, such as UUD no. 39 of 1991 on Human Rights, UUD (the constitution) no. 12 of 2005 concerning Civil and Political Rights, and Law no. 29 of 1991 concerning the Elimination of All Forms of Racial Discrimination. Second, specific regulations are considered discriminatory, for example, Law no. 01/PNPS/1965 concerning Prevention of the Abuse and Blasphemy of Religion, Joint Regulation of the Minister of Religion and the Minister of Home Affairs No. 09 of 2006, No. 08 of 2006 concerning Guidelines for the Implementation of Religious Harmony, Empowerment of Religious Forums, and the Establishment of Houses of Worship, and the application of Article 156A of the Criminal Code related to Blasphemy of Religion.[13] 
The articles then become a challenge for the government in realizing justice and fulfilling the rights of minorities. Therefore, some acts of violence or rejection of religious and belief activities seem to have distanced themselves from the values of diversity. And ironically, not a few discriminatory treatments are carried out by the state by issuing regulations that limit the freedom of citizens to worship.

Numerous solutions exist for eradicating discriminatory practices and injustice; however, two approaches are required: a politics of equality and strengthening of multiculturalism's capacity and understanding of democratic values. The first step is to advocate for a variety of unjust state policies. Certain legal products that are not consistent with the spirit of the 1945 Constitution and the modern world's development must be reviewed for relevance. Meanwhile, the second step aims to heighten the majority group's awareness of the importance of developing the values of equality, liberty, humanism, patriotism, and tolerance for diversity. If this plan is implemented, it has the potential to strengthen the country's democratic foundations and inspire global peace.

\subsection{Islam, Tolerance, and Peace Discourse}

\subsubsection{Islam and Religious Freedom}

In social interaction, Islam regulates the relationship between Muslims and nonmuslim to get rid of conflicts and wars. Islam maintains the relationship between the two to create peace and a sense of security.[14] In the Qur'an, Allah SWT. Emphasizes that if you wish, you can easily make people one.[15] In addition, Islam prioritizes compassion and tolerance, establishes Islamic brotherhood, and builds harmonious relations in addressing religious differences. All of that, part of the implementation of the values of rahmatan lil alamin in Islam.

Actually the message about freedom of religion (hurriyah al-aqidah), is in line with the values of freedom that belief cannot be forced. Allah SWT. said:

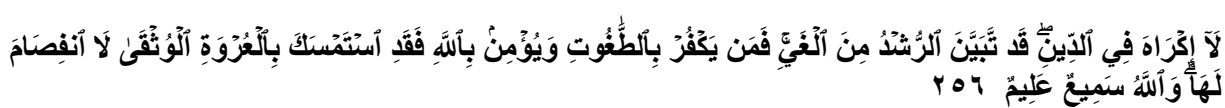

"There is no compulsion to (enter) religion (Islam); Indeed, the right path has become clearer than the wrong path. Therefore, whoever disbelieves in Taghut and believes in Allah, then indeed he has clung to a strong knot that will not break. And Allah is AllHearing, All-Knowing." [Al- Baqarah, 02:256].

Imam al-Qaffal al-Kabir (291-365 H./904-976 AD), Imam Fakhruddin Ar-Razi (455606 H./1150-1210 AD) states that Allah SWT. does not base one's faith based on pressure and coercion. On the other hand, Allah SWT. guarantee the freedom to make their own choices. In his reasoning, al-Razi emphasized that the world's life is dar alIbtila (a place of testing for humans), including accepting faith or rejecting it. That is, if one's faith can be forced, then the provisions of the life of the world as a place of testing become useless.[16] In his comments, al-Razi cites other supporting verses, including:

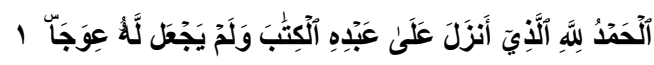

"Praise is to Allah who has sent down to His servant the Book (the Quran), and He has not caused crookedness in it." (Al-Kahfi, 18: 29). 


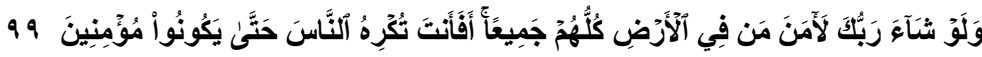

"And if your Lord had willed, all the people on earth would have believed. So do you (will) force people so that they will all become believers?". (Yunus, 10: 99).

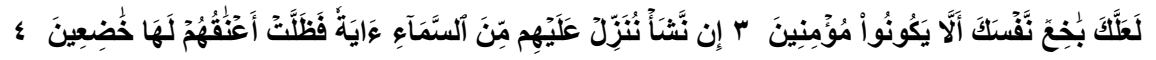

"Perhaps you (Muhammad) will destroy yourself because they do not believe. If we had wished, We would have sent down to them a miracle from the sky, so their necks will always bow to it." (Ash-Shu'ara, 26: 3-4).

Some of these verses, al-Razi reiterates, that the sentence "qad tabayana al-rusyd min al-ghay', further confirms the interpretation of freedom of faith/religion. With that sentence too, Allah SWT. Ensure that the truth of the Qur'an is specific and does not leave any explanation so that they believe without violence, intimidation, and coercion. That way, at least not denying taklif for life in the world.[16]

Al-Razi's interpretation, followed by other mufassir, such as Nizamuddin al-Hasan bin Muhammad an-Naisaburi (d. 805 H./1446 AD),[17] Jamaluddin As-Suyuthi (849911 H./1445-1505 AD),[18] and Ibn Qayyim al-Jauziyyah (691-751 H./1292-1350 AD).[19] In his commentary, Ibn Qayyim, as quoted by Yusri As-Sayyid Muhammad, the verse about the prohibition not to force in faith, is a verse with a nafi pattern but means nahi. The verse shows, never force someone to convert to Islam. And according to a trusted opinion (sahih), this verse indicates a universal meaning, applies to all circles. In another reference, continued Ibn Qoyim, among the policies of the Prophet. The Arabs converted to Islam voluntarily and based on their consciousness, without coercion or threats to maintain peace.[20]

\subsubsection{Islam and Religious Tolerance}

The teaching of religious tolerance must first be understood as an effort to interpret the noble values of Islam. Not only with fellow Muslims but also with non-muslim. The explanation is based on the word of Allah SWT:

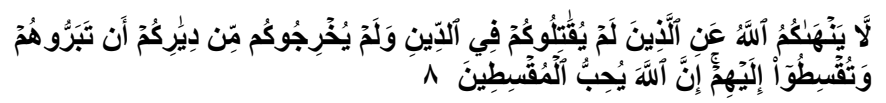

"Allah does not forbid you to do good and to do justice to those who do not fight you because of religion and do not (also) expel you from your country. Verily, Allah loves those who act justly." [Al-Mumtahanah, 60: 08].

In interpreting this verse, Imam al-Qusyairi reminded that when non-muslim are kind to Muslims, the Muslim community must also do the same.[20] The attitude, for example, is like the message of the Prophet SAW. Narrated by Bukhari and Muslims, Allah SWT. is a God full of compassion for his creatures. Thus, as the hadith narrated by Hakim At-Tirmidhi, Islam teaches to maintain affection with fellow Muslims and other religious people.

However, Islamic law experts provide certain limits in interacting with non-Muslims, including:

a. Do not exceed the limits of faith so that it has the potential to lead to kufr, such as acknowledging kufr and judging all (teachings) of true religion; 
b. Do not exceed the limits of the Shari'a so that you are trapped in the prohibition, for example, by admitting the kufr of non-muslim or tolerance accompanied by respect for kufr.[16]

c. Relations between Muslims and non-muslim are limited to social interactions, such as cooperation in business, visiting when sick, exchanging gifts, and serving meals.[21]

Even though scholars sometimes view each issue/case differently, some see it as a form of struggle for disobedience (I'anah ala al-ma'asyi), and others think otherwise. However, religious tolerance is actually by the principles of Islam as a friendly religion and a blessing for the universe, rahmatan lil alamin.

\subsubsection{Islam and Protection of Religious Activities}

Constitutionally, every citizen has the right to protect activities in carrying out their religion. They are given the freedom to carry out religious rituals based on their religion, free from pressure, intimidation, and persecution. In the history of Islam, the protection of religious rights can be seen in the Medina charter document (Charter of Medina), which was initiated by the Prophet Muhammad SAW; he emphasized that every citizen is given the freedom to embrace and carry out his religious rituals.[22]

The same incident was carried out by a friend of Khalid ibn Walid when he agreed with the 'Anat tribe. Khalid gave freedom to continue to carry out his religious activities, such as beating the bell, wearing the symbol of the cross, and other activities. Even houses of worship, such as churches, synagogues, and other places of worship, receive the same treatment and are not destroyed.[23]

In the Indonesian context, security protection for non-Muslims is a substantial part because it can minimize the occurrence of disputes, in addition to helping the government in maintaining social relations between citizens and ensuring national stability amid a pluralistic nation.[24] In Islam, such treatment cannot be categorized as protection against disobedience (I'anah ala al-ma'siyah). Even if you think so, it cannot be a single truth. Because even without providing security protection, non-Muslim religious rituals and traditions can still run, so the actions are taken (guaranteed freedom of worship) cannot be considered triggers in immorality.[25] Meanwhile, in the Maliki school, non-Muslim activities in carrying out their teachings cannot be categorized as immoral.[26]

Additionally, the Muslim community is required to provide protection and security guarantees in the event of several acts of terrorism that jeopardize religious freedom, such as threats against minorities, prohibitions, or the destruction of places of worship. As a means of articulating Islam's friendliness, this principle has been enshrined in the religion's fundamental tenets (Islam).[27]

According to Shaykh Ramadhan al-Buthi, the legality and most appropriate parameters for establishing houses of worship are determined by the needs (hajat) of non-Muslims to conduct religious activities. Because, in principle, there is no reason from an Islamic perspective — to prohibit or permit the establishment of a house of worship, except in cases of necessity.[14]

As a result, no one has the authority to prohibit, harm, or instill fear in the rights of non-Muslim worship, as long as the actions are carried out following applicable procedures and regulations, as Islam has granted the freedom to construct houses of worship as needed. Furthermore, these actions contradict Islamic teachings by 
prohibiting and destroying places of worship. Furthermore, if terrorizing with suicide bombings is the goal, Islam is adamantly opposed.

\section{Conclusion}

The challenges and dynamics of building houses of worship are faced with discriminatory decisions in regulations set by the government. Several incidents of rejection and destruction of places of worship, such as the Yasmin Indonesian Christian Church (GKI) in Bogor and the Al-Hidayah Mosque in North Minahasa, are facts from the peak of acts of intolerance in Indonesia.

Regulations No. 09/2006 and No. 08/2006 between the Ministers of Religion and Home Affairs, implementing the value of justice bias for minorities. Although this decision was intended to advocate - one of them - for the establishment of places of worship, it has instead been used as a legitimacy tool for restricting religious freedom. As a pluralistic society, religious freedom must be founded on the values of unity and diversity. As a result, the two ministers' 2006 Decree on the establishment of houses of worship must be viewed as a legal basis for ensuring religious freedom in Indonesia.

Meanwhile, Islam considers that this issue has come out of the message of mercy because religion (Islam) must be based on voluntariness, not by coercion, intimidation, and threats. The opinion, as expressed by Imam al-Qaffal al-Kabir (291-365 H./904-976 AD) and Imam Fakhruddin Ar-Razi (455-606 H./1150-1210 AD), says that Allah SWT does not base one's faith based on pressure and coercion. Therefore, Islam assesses the construction of houses of worship does not need to be questioned, as long as based on need (hajjah). It has been by the regulations and decisions that the government has set.

\section{References}

[1] B. Sirait, "Ancaman Diskriminasi Minoritas Dan Hilangnya Multikulturalisme Di Indonesia: Studi Kasus Penutupan Gki Yasmin Bogor,” Polit. J. Ilmu Polit., vol. 10, no. 1, p. 28, Apr. 2019,

[2] "Polisi Tahan 6 Terduga Perusakan Bangunan untuk Ibadah Umat Muslim di Minahasa Utara,"

Kompas, 2020. https://regional.kompas.com/read/2020/01/31/21323771/polisi-tahan-6-terdugaperusakan-bangunan-untuk-ibadah-umat-muslim-di.

[3] "Pembangunan gereja di Tanjung Balai Karimun ditolak warga meski sudah kantongi IMB, mengapa aksi intoleransi terus terjadi?," Jakarta, 2020. https://www.bbc.com/indonesia/indonesia51444700 .

[4] A. Asroni, "Menyegel 'Rumah Tuhan': Menakar Kadar Kemaslahatan Peraturan Bersama Menteri Agama dan Menteri Dalam Negeri No. 9/ 2006 dan No. 8/2006 dalam Mereduksi Konflik Pendirian Rumah Ibadah di Indonesia," Reli. J. Stud. Agama-Agama, vol. 08, p. 01, 2012.

[5] A. N. Burhani, Dilema minoritas di Indonesia, 01 ed. Jakarta: PT. Gramedia Pustaka Utama, 2020.

[6] M. Crouch, "Implementing the regulation on places of worship in Indonesia: New problems, local politics and court action," Asian Stud. Rev., 2010, doi: 10.1080/10357823.2010.527921.

[7] B. Bungin, Analisis data penelitian kualitatif. Depok: PT RajaGrafindo Persada, 2007.

[8] L. J. Moleong, Metodologi Penelitian kualitatif. Bandung: Remaja Rosdakaya, 2021.

[9] M. Yusuf Asry, Pendirian rumah ibadat di Indonesia: pelaksanaan peraturan bersama Menteri Agama dan Menteri Dalam Negeri no. 9 dan 8 tahun 2006. Jakarta: Badan Litbang dan Diklat Kemenag RI, 2011.

[10] N. S. Putri, "Pelaksanaan Kebebasan Beragama di Indonesia (External Freedom) Dihubungkan Ijin Pembangunan Rumah Ibadah," J. Din. Huk., vol. 11, no. 2, May 2011,

[11] B. Rohmah and R. D. P. Nugroho, "Assistance for the Construction of Houses of Worship: One 
of the Practices of Money Politics in the Context of Criminal Acts in the Perspective of Criminal Law and ...," Law Res. Rev. Q., 2018

[12] B. A. Hutabarat, "Evaluasi terhadap Peraturan Bersama Menteri Tahun 2006 tentang Pendirian Rumah Ibadah," Soc. Dei J. Agama dan Masy., vol. 4, no. 1, p. 8, Oct. 2017,

[13] M. Syafi'ie, "Ambiguitas Hak Kebebasan Beragama di Indonesia dan Posisinya Pasca Putusan Mahkamah Konstitusi," J. Konstitusi, 2016,

[14] S. S. R. Al-Buthi, Al-Jihad fi Al-Islam Kaifa Nufhimu wa Kaifa Numarisuh, 01 ed. Bairut: Dar Al-Fikr Al-Mu'asirah, 1993.

[15] A.-I. al-H. I. A. al-F. Ibnu Katsir, Tafsir al-Qur'an al-Adzim. Bairut: Dar al-Baz, 1980.

[16] A. A. M. ibn U. ibn H. ibn H. Fakhruddin Al-Razi, Mafatih Al-Ghaib. Bairut: Dar al-Ihya alTurats al-Arabi (Maktabah Syamilah, v. 10), 1420.

[17] N. al-H. ibn M. ibn Husain al-Naisabur, Gharaib al-Qur'an wa Raghaib al-Furqon. Bairut: dar Al-Maktabah Al-Ilmiyyah, 2004.

[18] J. As-Suyuthi, Qath Al-Azhar di Kasyf Al-Asrar. Qatar: Wizarah Al-Auqaf wa As-Syu'un AlIslamiyyah, 1994.

[19] I. Q. Al-Jauziyyah, Hadaya Al-Hayara di Ajwibah Al-Yahud wa An-Nashara. Jedah: Majma’ AlFiqh Al-Islami.

[20] A. K. ibn H. Al-Qusairi, Tafsir Al-Qusairi. Bairut: Dar 'Alam Al-Kutub.

[21] S. M. Ali Jum'ah, Al-Bayan Lima bi Sahl Al-Adhan. Kairo: Dar Al-Uswah, 2003.

[22] A. M. ibn Hisyam, Sirah An-Nabi. Thanta: Dar As-Shahabah li At-Turats, 1995.

[23] A. Y. Y. bin I. Ibrahim, Kitab Al-Kharraj. Bairut: Dar Al-Ma'rifah, 1979.

[24] A. M. I. A. A. Abdissalam, Qawaid Al-Ahkam fi Masalih Al-Anam. Kairo: Maktabah Kuliyat AlAzhar, 1991.

[25] Z. ibn Nujaim, Al-Bahr Ar-Raiq Syarh Kanz Ad-Daqaiq. Bairut: Dar Al-Ma'rifah, 2001.

[26] M. ibn Y. Al-Abdari, At-Taj Al-Iklil li Mukhtashar Khalil. Bairut: Dar Al-Fikr Al-Mu'asirah.

[27] A. bin Bayyah, Al-Irhab At-Tasykhis wa Al-Hulul. Riyadh: Ubikan, 2008. 